\title{
Çırçır İşletmelerinin Pamuk Lif Kalitesine Bakış Açıları
}

\author{
Ceren ODABAŞIOĞLU ${ }^{1 *}$, Osman ÇOPUR ${ }^{1}$ \\ ${ }^{1}$ Harran Üniversitesi, Ziraat Fakültesi, Tarla Bitkileri Bölümü, Şanlıurfa-Türkiye \\ "Sorumlu yazar: cerenodabasioglu@harran.edu.tr
}

\begin{abstract}
Öz
Bu çalışma, çırçır işletmelerinin pamuk lif kalitesine bakış açılarını değerlendirmek üzere 2015-2016 sezonunda yapılmıştır. Bu amaçla, Şanlıurfa organize sanayi bölgesi, Viranşehir, Mardin yolu ile Akçakale yolu üzerindeki toplam 50 çırçır işletmesi ile görüşülerek çırçır işletmelerinin pamuk lif kalitesi ile ilgili fikirlerini belirtmeleri istenmiştir. Çalışmada, çırçır işletmeleri ile yapılan görüşmelerde; işletmeciye, kullandığı çırçırlama yöntemi, makine sayısı, çırçır randıman oranı, pamukta kirlilik durumu, çırçır işletmelerinin karşılaştı̆̆ı sorunlar ile çiftçilerden beklentileri sorularak Şanlıurfa ilinde çırçır işletmelerinin kullandığı çırçırlama teknolojisi ile işletme kapasitesi, bölge pamuklarının randıman durumu, işletmeye getirilen pamukların kirlilik durumu, işletmelerin çiftçilerle yaşadıkları sorun ve çözüm önerileri belirlenmeye çalışılış̧ır. Anket yapılan çırçır işletmeleri; işletmeye getirilen pamukların genellikle kirli olduğunu, bu sorunun çözümü için üreticilerin yaprak döktürücüleri zamanında ve yeterli miktarda uygulaması gerektiğini bildirmişlerdir. Kütlü pamukta bulunan yabancı maddelerin ve kirliliğin pamuğun çırçır randımanını düşürdüğünü, lif kalitesini ve lif uzunluğunu etkilediğini belirtmişlerdir. Diğer bir sorun olarak da bölgedeki çırçır işletme sayısının çok fazla olduğunu, bu yüzden rekabetin arttı̆ı̆ı ıe pamuk fiyatının sabit olmadığını, işletmelerin verimli çalıştııımadığını ve işletmelerin yenilenmesi ve teknoloji transferi için çıç̧ır işletmelerinin destekleme kapsamına alınması gerektiğini belirtmişlerdir.
\end{abstract}

Anahtar Kelimeler: Şanlıurfa, Pamuk, Çırçır işletmesi, Lif kalitesi

\section{Cotton Fiber Quality Perspective of Cotton Gin Companies}

\begin{abstract}
This study was carried out in the 2015-2016 season to evaluate the cotton fiber quality perspectives of ginning companies. For this purpose, totaly 50 ginning companies' which are located in Sanliurfa and Viransehir industrial zones, Mardin route and Akçakale route, views on cotton fiber quality of the business has been requested. In the study, in an interview with gin companies; using ginning process, number of machines, ginning efficiency ratio, pollution situation in the cotton ginning company of the problems faced by asking the expectations of the farmers in Sanliurfa province in the ginning company with a capacity of ginning technology is used by businesses of efficiency status of cotton, pollution status of cotton brought, operation and problems faced by farmers the solutions were determined. Surveyed ginning companies reported that the cotton which they buy is always dirty, so for the solution of this problem sufficient amounts of defoliants should be applied by farmers. They stated that the foreign materials and dirtiness in seed cotton, reduce gin efficiency, the quality of fiber and affect the fiber length. Another problem was that it is too much the number of ginning companies in the area, so the cotton prices is not constant and competition increased, companies are inefficient operation and that the company of renewal and should be covered to support the company gin for technology transfer is reported.
\end{abstract}

Key Words: Sanliurfa, Cotton, Ginning company, Quality of fiber 


\section{Giriş}

Pamuk bitkisi, lif ve tohumu ile dünya tarımını ve ticaretini yakından ilgilendirmektedir. Pamuk, birçok sanayi kolunda hammadde olarak kullanılmakta ve yarattığı istihdam nedeniyle ülke ekonomisinde stratejik bir öneme sahiptir.

Bir endüstri bitkisi olan pamuk, lifi ile tekstil, çiğidi ile yağ sanayine hammadde sağlaması, küspesi ile hayvancilı̆ın gelişmesine katkıda bulunması nedeniyle ülke ekonomisinde önemli bir yer tutmaktadır (Çopur, 2014). Ülkemizde pamuk üç önemli bölgede üretilmektedir. Bunlar Ege, Çukurova ve Güneydoğu Anadolu Bölgeleridir. Şanlıurfa ilinin de yer aldığı Güneydoğu Anadolu Bölgesi, ülke pamuk üretiminin $\% 60^{\prime} ı$ ı karşılamaktadır (TÜiK, 2016).

Pamuğun tarımıyla başlayan süreç, hasat edilmesi, çırçırlanarak lif ve çiğit elde edilmesi, lifin tekstil ve diğer sanayilere hammadde olması, çiğitin lintergin işleminden sonra elde edilen linter pamuğun selüloz kimya sanayi, yatak ve dolgu endüstrisi ile savaş sanayisine kadar çeşitli sektörlere hammadde olması, çiğitin ise hayvan yemi ve yağ sanayisi gibi sanayilere hammadde olması şeklinde devam etmektedir.

Genel tanımlarıyla; ilk etapta çiğitli (kütlü) pamuğun elyafının çekirdeğinden (çiğidinden) ayrılması işlemini yapan işletmelere çırçırprese fabrikası, ikinci etapta linter pamuğunun çekirdek üzerinden sıyrılması işlemini yapan işletmelere linter-prese fabrikası, çırçırlama ve iplik imalatı aşamalarında oluşan pamuk lifi döküntülerinin balya haline getirilmesi işlemini yapan işletmelere ise lif döküntüsü prese fabrikası denilmektedir (Özel, 2015).

Çırçır, linter ve lif döküntüsü prese fabrikalarının yapıları incelendiğinde, çok entegre ve komplike işletmeler olmadığı görülmektedir. Çırçır-prese işletmeleri; kütlü depoları, prese (balya) depoları, çiğit depoları, avlu, sundurma, kantar bölümü, randıman tespit odası, tasnif odası, çırçır makineleri bölümü, prese kısmı, idare binası ve yakıt bölümü gibi kısımlardan oluşmaktadır. Çırçırprese fabrikalarında makine ve teçhizat donanımları olarak; kütlü pamuk iletim boruları, kütlü pamuk iletim aspiratör ve fanları, kütlü ve lif pamuk temizleyicileri, rollergin veya sawgin çırçır makineleri, lif pamuk taşıma bantları, separatör, şiftleme makinesi, balya presesi, çiğit helezonları, kantar ve rutubet ölçme cihazı gibi ekipmanlar bulunmaktadır.

Tarıma dayalı sanayideki gelişmeler doğrudan üreticiyi etkilemektedir. Çırçır işletmeleri pamuğu hammadde olarak kullanan sanayi kollarından en önemlisidir. Çırçır fabrikaları üretici ile tekstil firmaları arasında köprü görevi görmektedir. Pamuk lifleri doğru işlenmediği takdirde lif kalitesinde önemli kayıplar ortaya çıkmaktadır. Bu yüzden çırçır fabrikaları, üreticiden aldığı kütlü pamuğu en uygun şekilde işleyerek tekstilcinin taleplerini karşılamak durumundadır.

Lif kalitesini etkileyen önemli etmenlerden biri olan nem fazlalığı, lifin rengini bozabilmekte ve parlaklığını azaltabilmektedir. Ayrıca, çırçırlama esnasında birçok sorunla karşılaşılmasına neden olmaktadır. Bununla birlikte, lifteki nemin azlığı çırçırlama esnasında lifte kırılmaların artmasına neden olmakta ve lifin kalitesini olumsuz yönde etkilemektedir. Çırçırlama etkinliğini etkileyen bir diğer faktörde yabancı maddedir. Kirli pamukların lif temizleyicilere alınması esnasında lif kayıpları yanında, liflerin birbirine dolanarak nep oluşturma riski artabilmektedir (Oğlakçı, 2012). 
Bu çalışmada amaç, lif pamuk üretiminde çırçır işletmelerinin lif kalitesi ile ilgili etki ve bakış açılarını tespit edebilmek ve kütlü pamuğun işlenmesi esnasında ortaya çıkan sorunlara çözüm üretebilmek amacıyla yürütülmüştür.

\section{Materyal ve Metot}

\section{Materyal}

Bu çalışmada materyal olarak Şanlıurfa Organize Sanayi Bölgesi, Mardin yolu ile Akçakale yolu üzerinde bulunan ve faaliyet gösteren 50 adet çırçır işletmesine sorulan anket soruları ve işletmede bulunan yetkili kişilerin sorulara verdiği yanıtlar kullanılmıştır.

\section{Metot}

$\mathrm{Bu}$ çalışmada, genel anlamda çırçır işletmelerinin pamuk lif kalitesine bakış açıları araştırılmıştır. Bunun için sözü edilen yerlere gidilerek işletmelere yönelik bir dizi sorudan oluşan anket çalışması yapılımıştır. Çalışmanın verileri, yüz yüze görüşme yoluyla elde edilmiştir. Çalışmadan elde edilen veriler 2015 yılı üretim sezonuna aittir. Çırçır işletmeleri ile gerçekleştirilen anket çalışması ile işletmede bulunan yetkiliye;
- Kullanılan çırçırlama yöntemi,

- Makine sayısı,

- Çırçır randıman oranı,

- Pamukta kirlilik durumu,

- Çırçır işletmelerinin karşılaştığı sorunlar,

- Çırçır işletmelerinin çiftçiden beklentisi,

- Balyalama ile ilgili sorular sorularak anket çalışması gerçekleştirilmiştir.

Yapılan araştırma sonucunda elde edilen veriler öncelikle bilgisayar ortamına kaydedilmiş ve veri tabanı oluşturulmuştur. Daha sonra veriler SPSS istatistiksel analiz programı ile analiz edilmiştir.

\section{Araştırma Bulguları ve Tartışma}

Çırçır işletmeleri ile yapılan anket çalışmasında, işletmede bulunan yetkiliye 20 adet soru sorulmuş ve cevapları analiz edilmiştir. Yapılan analiz sonucunda elde edilen veriler grafikler halinde belirtilmiştir.

Çırçır işletmelerine kullandıkları çırçırlama yöntemini sorduğumuzda işletmelerin verdikleri yanıtlar Şekil 1'de gösterilmektedir.

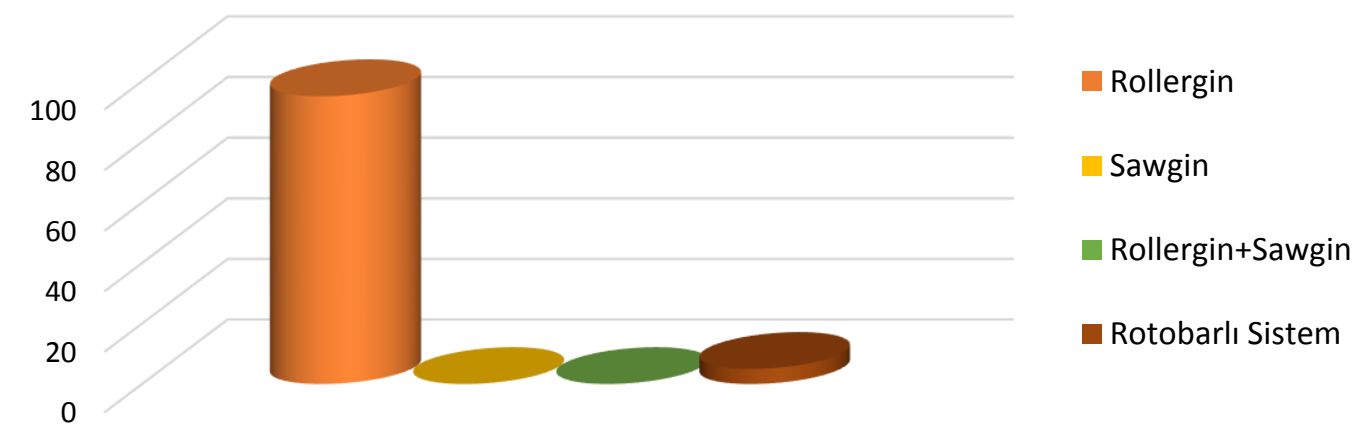

Şekil 1. Çırçır işletmelerinde kullanılan çırçırlama yöntemi

Figure 1. The method used for ginning in cotton ginning companies 
Buna göre işletmelerin \%95'i Rollergin Çırçır Makinası ve \%5'i Rotobarlı Sistem kullandığını belirtmiştir. Sawgin Çırçır Makinası ve hem Rollergin hem de Sawgin çırçır makinalarını aynı fabrikada kullanan işletmelerin mevcut olmadığı belirlenmiştir.

Çırçır işletmelerinde bulunan makine sayısını sorduğumuzda işletmelerin \%50'sinin 50-70 adet, \%38'inin 30-50 adet, \%8'inin 90120 adet ve $\% 4^{\prime}$ ünün ise $70-90$ adet Rollergin çırçır makinesine sahip olduğu ortaya çıkmıştır. Rotobarlı sisteme sahip işletmelerin ise 12 adet makinaya sahip olduğu ortaya çıkmıştır. Çırçır işletmelerine bölgedeki çırçır işletme sayılarının yeterli olup olmadığını sorduğumuzda işletmelerin \%100'ü sayının yeterli olduğunu hatta fazla olduğunu belirtmişlerdir. Suruç Ovasının da sulamaya açılmasıyla da pamuk ekiminin yapılacağını, ancak o zaman sayının yeterli düzeyde olabileceğini belirtmişlerdir.

İşletmelere fabrikalarının çırçır randıman oranlarını sorduğumuzda aldığımız yanıtlar Şekil 2'de gösterilmiştir.

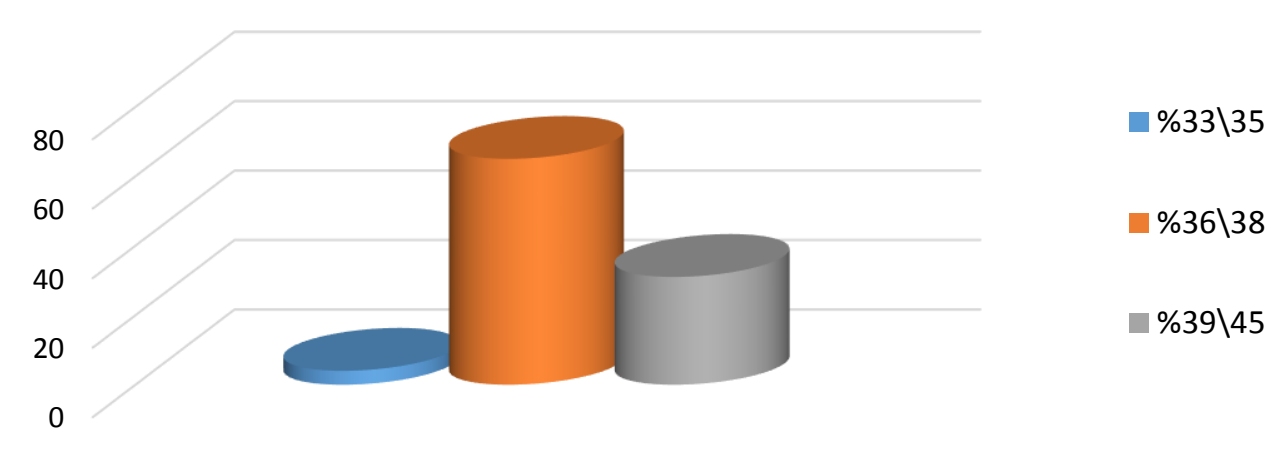

Şekil 2. Çırçır işletmelerinin çırçır randıman oranı

Figure 2. Ginning efficiency ratio of ginnig companies

İşletmelerin \%65'i randıman oranlarının \%36-38 olduğunu, \%31'i \%39-45 olduğunu ve \%4'ü de \%33-35 olduğunu belirtmiştir.
Çırçır randımanı elyafın kütlü pamuğa oranı olarak tanımlanır ve \% olarak ifade edilir. Çırçır randımanının belirlenmesinde aşağıdaki formül kullanılmaktadır (Şekil 3).

Çırçır Randımanı $(\%)=\frac{\text { Lif }(\mathrm{g})}{\operatorname{Lif}(\mathrm{g})+\text { Tohum }(\text { Kütlü pamuk })(g)} \times 100$

Şekil 3. Çırçır randımanı formülü

Figure 3. Ginnig ratio formula

Çırçır işletmelerine getirilen kütlü pamuğun kirlilik oranını sorduğumuzda işletmelerin \%49'u kütlü pamuğun kirliliğinin \%40-50 arasında olduğunu, \%22'si \%5-10 arasında olduğunu, \%14'ü \%10-20 arasında olduğunu ve \%13'ü ise \%20-30 arasında olduğunu belirtmiştir. İşletmelerin \%2'si ise kirlilik durumunun hasadın el ile ya da makine ile yapılmasına bağı olarak değiştiğini belirtmiştir. İşletmelerinde kullandıkları temizleme ünitesinin ne olduğunu sorduğumuz işletmelerin $\% 82$ 'si hem kütlü hem de lif temizleme sistemini kullandıklarını, $\% 18^{\prime} i$ ise kütlü temizleme sistemini kullandıklarını belirtmişlerdir. 
İşletmecilere kütlünün ve lifin temizleme işlem sayısının artmasının lif üzerinde ne gibi bir etki bıraktığını sorduğumuzda aldığımız yanıtlar Şekil 4.'de gösterilmiştir.

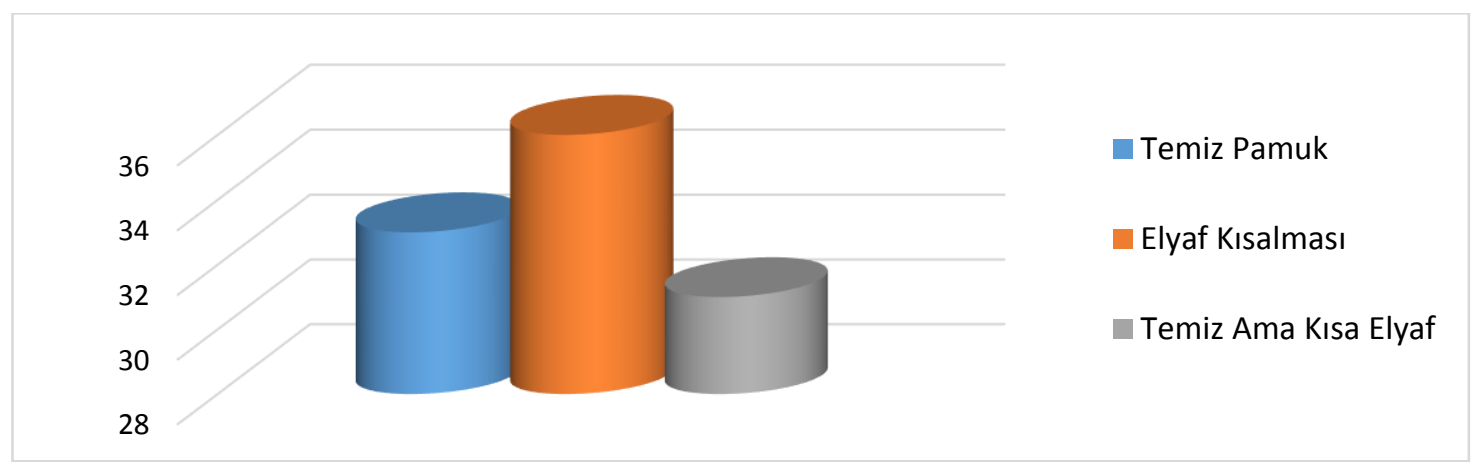

Şekil 4. Temizleme işlem sayısının lif üzerindeki etkileri

Figure 4. Effects on the fibers of the number of cleaning process

İşletmelerin \%36'sı temizleme işlem sayısının artması sonucu elyafın kısaldığını, $\% 33^{\prime}$ ü pamuğun temizlendiğini ve $\% 31$ 'i ise elyafın temizlendiğini ama kısaldığını belirtmiştir.
Çırçır işletmelerine kirlilik sorununun çözümüne yönelik bir çözüm önerileri olup olmadığını sorduğumuzda işletmelerin verdikleri yanıtlar Şekil 5'de görüldüğü gibidir.

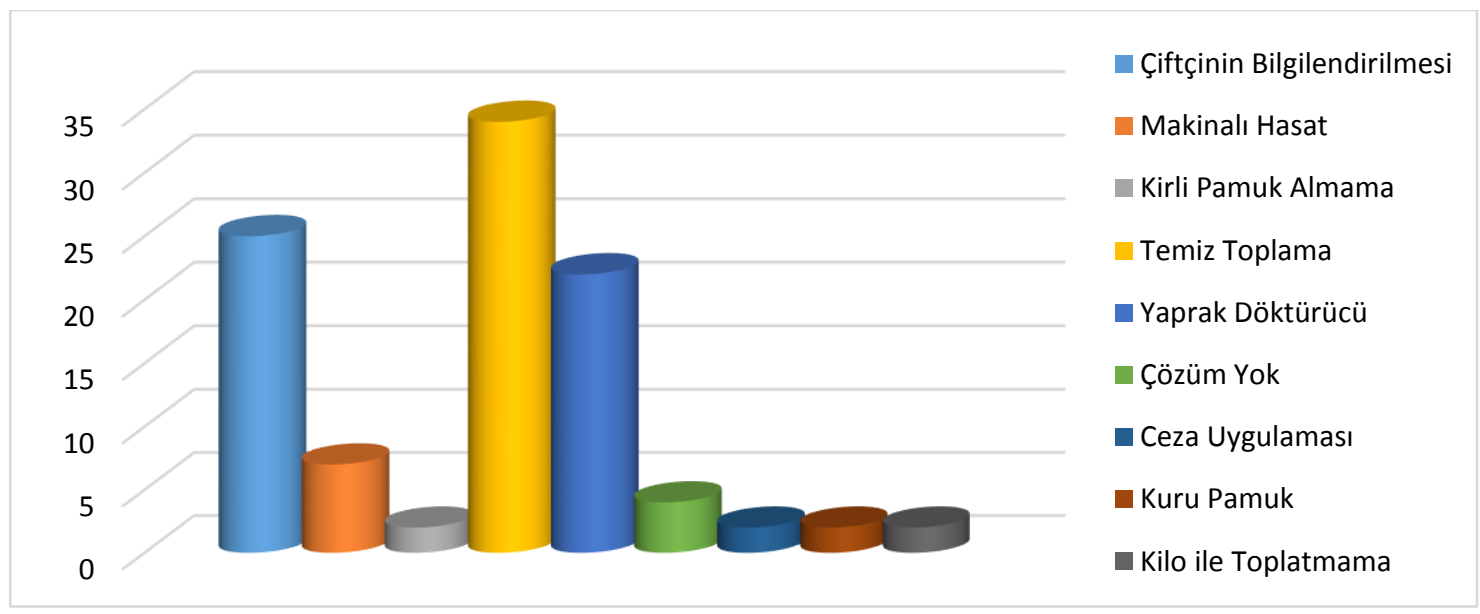

Şekil 5. Çırçır işletmelerinin kirlilik sorununa çözüm önerileri

Figure 5. Ginning companies' solutions to the problem of dirtiness

Buna göre, işletmelerin \%34'ü pamuğun temiz toplanması gerektiğini, \%25'i çiftçinin bilgilendirilmesi gerektiğini, \%22'si yaprak döktürücülerin zamanında ve yeterli miktarda atılması gerektiğini, \%7'si hasadın makine ile yapılması gerektiğini belirtmiştir. İşletmelerin $\% 8^{\prime} i$ işletmelerin kirli pamuk almaması gerektiğini, kirli pamuk toplayan üreticilere ya da alan işletmelere cezai işlem uygulanması gerektiğini, pamuğun kuru toplatılması gerektiğini ve kilo ile toplatılmaması gerektiğini belirtmişlerdir. İşletmelerin \%4'ü ise kirlilik konusuna herhangi bir çözüm getirilemeyeceğini belirtmiştir.

Çırçır işletmelerine avantajı hasat yönteminin ne olduğunu sorduğumuzda 
işletmelerin \%80'i makina ile hasadı avantajı bulurken, işletmelerin \%20'si el ile hasat yöntemini avantajlı bulduğunu belirtmiştir. İşletmelerin \%78'i daha temiz olduğu, \%11'i elyafın kalitesini koruduğu ve yine $\% 11$ 'i ucuz olduğu için el ile hasat yöntemini avantajı bulduklarını belirtmiştir. İşletmelerin \%37'si ise daha temiz olduğu, yine $\% 37$ 'si temiz ve randımanının yüksek olduğu ve $\% 26$ sı daha hızlı olduğu için makinalı hasadı avantajı bulduklarını belirtmiştir.
İsletmelerine getirilen kütlü pamuğun nem ve sıcaklı̆ı̆ı nasıl ölçtüklerini sorduğumuzda; işletmelerin \%87'si kütlünün nem ve sıcaklı̆ı̆ı makine ile ölçtüklerini, \%11'i el ile kontrol ettiklerini ve \%2'si ise ölçmediklerini belirtmişlerdir.

İşletmelerine getirilen nemli kütlüyü kurutma yöntemlerini sorduğumuz işletmelerin verdikleri cevaplar Şekil 6.'da görüldüğü gibidir.

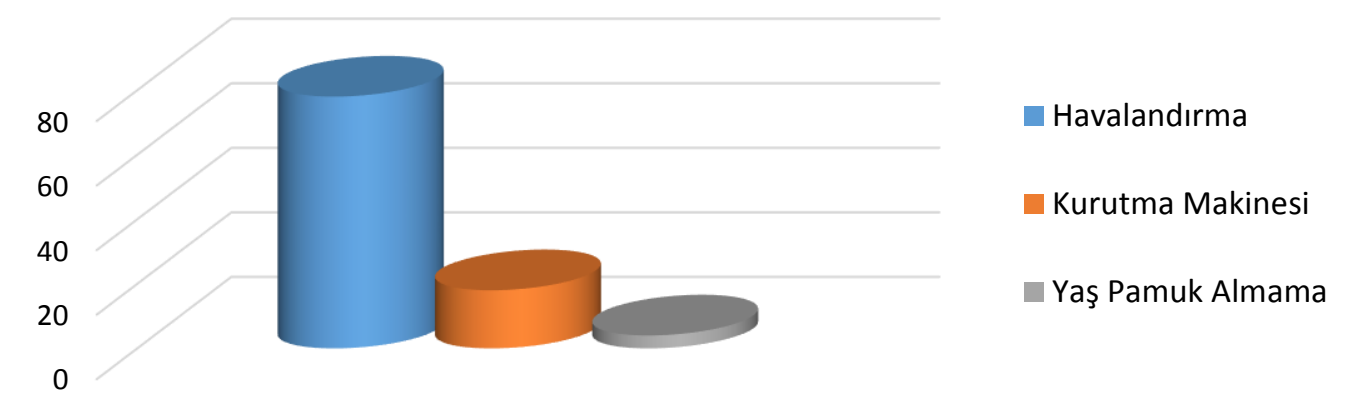

Şekil 6. Çırçır işletmelerinin kütlüyü kurutma yöntemi

Figure 6. Seed cotton drying method of ginning companies

Buna göre, işletmelerin $\% 78$ i kepçe ile havalandırarak kendi yöntemleriyle kütlüyü kuruttuklarını, \%18'i kurutma makinası ile kuruttuklarını ve \%4'ü de yaş pamuk almadıklarını belirtmiştir. Kütlü pamuğun güvenilir bir şekilde depolanabilmesi için nem düzeyinin $\% 12$ 'den az olması gerekmektedir. Bu durumda, lif nemi \%9'dan az ve tohum nemi de \%13'den az olmalıdır. Güvenilir bir depolama için kütlünün tarlada kurutulması ya da hasat sırasında nem kaybına uğramasının sağlanması gerekmektedir (Oğlakçı ve ark., 2007).

Pamuğun bölge ekonomisine katkısının olup olmadığını sorduğumuzda; işletmelerin $\% 56$ 'sı pamuğun bölge ekonomisine katkısının olmadığını, \%44'ü ise katkısının olduğunu belirtmiştir. Pamuğun bölge ekonomisine olan katkısını arttırabilmek için önerilerini sorduğumuz işletmelerin \%22'si çırçır işletmelerinin desteklenmesi gerektiğini, \%16'sı çiftçiye eğitim verilmesi gerektiğini, \%13'ü istihdamın arttırıması gerektiğini, \%11'i fiyatın arttırılması gerektiğini ve yine \%11'i kalitenin arttırılması gerektiğini belirtmiştir. İşletmelerin \% $\%$ 'si pamuk ekim alanının arttırılması gerektiğini, yine $\% 7^{\prime}$ si pamuk fiyatlarının sabitlenmesi gerektiğini ve yine $\% 7$ 'si ithal pamuğun engellenmesi gerektiğini belirtmiştir. İşletmelerin \%2'si kooperatifleşmenin artması gerektiğini belirtirken $\% 4$ 'ü ise herhangi bir önerisinin olmadığını belirtmiştir.

İşletmelerinde bulunan pamuk eksperinin eğitim durumunu sorduğumuzda işletmelerin verdikleri yanıtlar Şekil 7'de gösterilmektedir. 


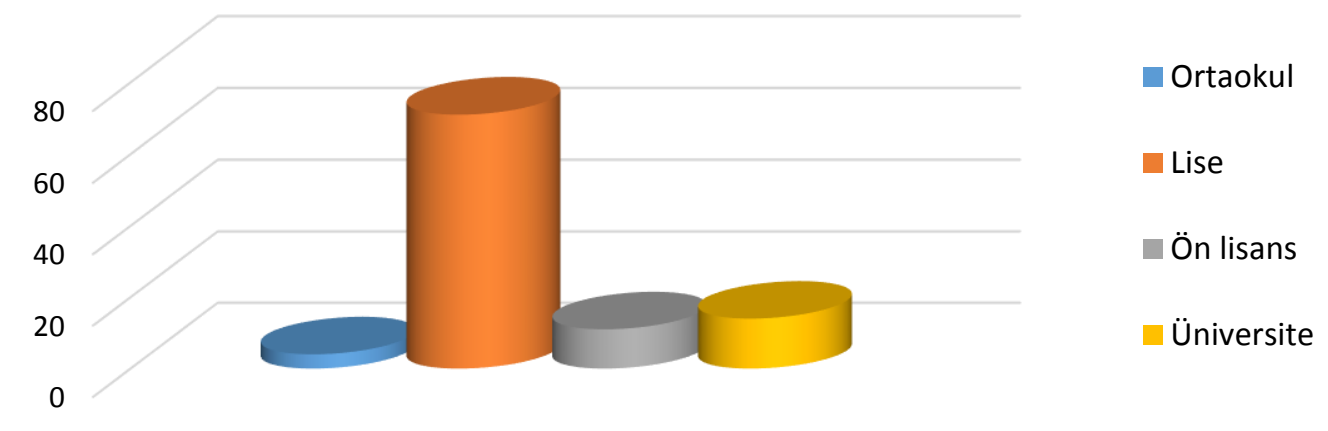

Şekil 7. Çırçır işletmelerinde bulunan pamuk eksperinin eğitim durumu

Figure 7. Education level of experts in which cotton ginning companies

Işletmelerde istihdam edilen eksperlerin $\% 71^{\prime}$ inin lise, \%14'ünün üniversite, \%11'inin ön lisans ve \%4'ünün ortaokul mezunu olduğu saptanmıştır.

Üreticiden ne gibi beklentilerinin olduğunu sorduğumuz işletmelerin $\% 73^{\prime}$ ü kaliteli ve temiz pamuk istediğini, $\% 18^{\prime} i$ üreticilerin daha bilinçli olması gerektiğini, $\% 5$ 'i üreticilerin anında para talep etmemesi gerektiğini, \%2'si tüccarların aradan çıkartılması gerektiğini ve yine $\% 2$ 'si pamuk ekilmesini istediğini belirtmiştir.

Karşılaştıkları sorunların neler olduğunu sorduğumuz bir diğer soruya; işletmelerin $\% 52$ 'si gerek alımda gerekse satış aşamasında pazarlama sorunuyla karşılaştıklarını, \%4'ü güven sorunu yaşadıklarını ve yine $\% 14^{\prime}$ ü bilinçsizlikle mücadele etmeye çalıştıklarını belirtmişlerdir. İşletmelerin \%7'si girdilerin çok pahalı olduğunu, \%5'i kalifiye eleman bulmakta zorluk çektiklerini, \%2'si destekleme alamadıklarını ve yine $\% 2$ 'si nemli pamuk sorunuyla karşılaştıklarını belirtmişlerdir. İşletmelerin \%4'ü ise herhangi bir sorunla karşılaşmadıklarını söylemiştir.

Tek balya kontrol sistemi hakkında bilgi sahibi olup olmadıklarını sorduğumuz işletmelerin verdikleri yanıtlar Şekil $8^{\prime}$ de gösterilmektedir.

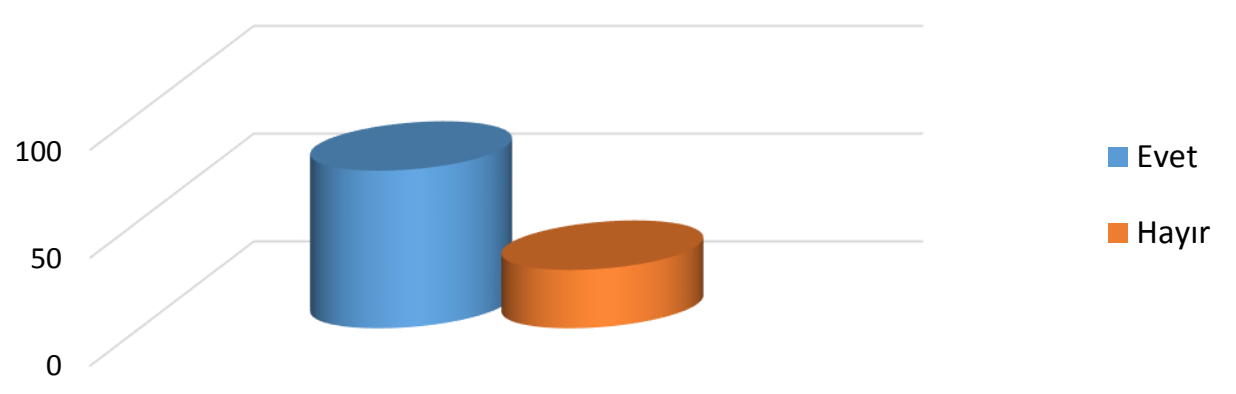

Şekil 8. Çırçır işletmelerinin tek balya kontrol sistemi hakkında bilgi sahibi olma durumu Figure 8. Having information about a single bale control system of cotton ginning companies

Buna göre, işletmelerin \%73'ü bilgi sahibi olduklarını ancak uygulamadıklarını, \%27'si ise bilgilerinin olmadığını belirtmişlerdir. Tek balya sistemi, kalite standardizasyonunda her bir balyanın kalitesinin lif analiz cihazları ile belirlenen, fiyatı kalite kriterlerine göre oluşturan, pamuk üretimi yapan ülkelerde yaygın olarak kullanılan bir sistemdir (Kaya ve 
ark., 2007). Tek balya sistemi hakkında bilgi sahibi olup, ancak uygulamayan işletmelere neden uygulamadıklarını sorduğumuzda, kendileri için ek maddi külfet olduğunu, HVI cihazının bölgede yeterli sayıda olmadığını, bölgede mevcut olan cihazın güvenirliliğinin olmadığını belirtmişlerdir.

İşletmelerinin denetlenme sıklığını sorduğumuz işletmelerin \%38'i sezonda 1-2 kez, \%13'ü sezonda 3-4 kez ve \%4'ü de sezonda ayda bir kez denetlendiklerini belirtmişlerdir. İşletmelerin $\% 45^{\prime} i$ ise denetlenmediklerini belirtmişlerdir.

Tohum kabuğu kalitesi hakkında bilgi sahibi olup olmadıklarını sorduğumuz bir diğer soruya; işletmelerin \%82'si bilgi sahibi olmadığını belirtirken işletmelerin \%18'i bilgi sahibi olduğunu belirtmiştir. Kütlü pamuğun çırçırlama sırasındaki sahip olduğu nem düzeyi, tohumun kırılmasına ve tohumdan kopan parçacık miktarı üzerine etkili olabilmektedir. Tohum nem düzeyi düşük kütlü pamukların çırçırlanması, tohumların kırılma miktarını arttırabilmekte, kırılan bu tohum parçacıkları life karışarak lif pamukta istenmeyen düğümcüklerin oluşmasına neden olmaktadır. Ayrıca nem düzeyi yüksek olan kütlü pamukların çırçırlanması ise tohum kabuğunda kopmalara neden olabilmekte ve bu kopan lifli tohum kabuğu parçacıkları, lif pamuğa karışarak yine lif pamukta düğümlenmelere neden olmaktadır. Bu durum daha sonraki iplik yapım aşamasında ve sonraki aşamalarda kalite bozukluklarının ortaya çıkmasında oldukça önemli rol oynamaktadır (Tümer, 2010).

Çırçır işletmelerine lif kalitesini arttırmak için önerileri olup olmadığını sorduğumuzda aldığımız yanıtlar Şekil 9'da gösterilmektedir.

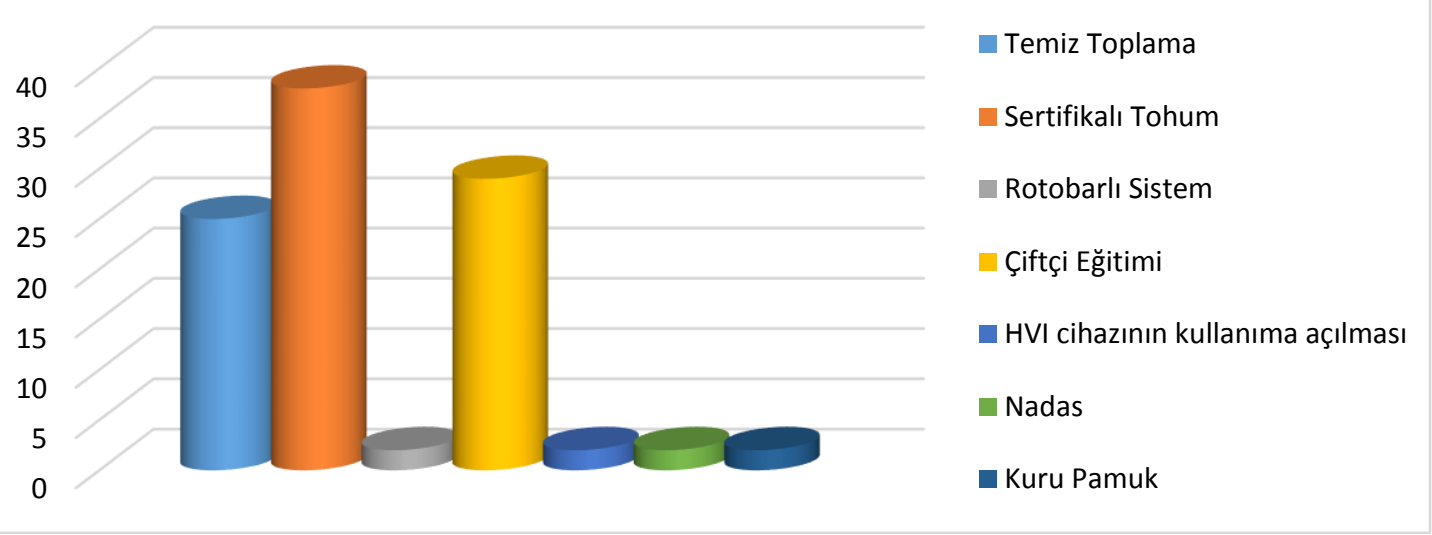

Şekil 9. Çırçır işletmelerinin lif kalitesini artırmak için önerileri

Figure 9. Suggestions for improve the quality of fiber of ginning companies

Buna göre, işletmelerin $\% 38^{\prime} i$ sertifikalı tohum kullanılması gerektiğini, \%29'u çiftçinin eğitilmesi gerektiğini, \%25'i pamuğun temiz toplanması gerektiğini belirtmişlerdir. İşletmelerin $\% 8^{\prime} \mathrm{i}$ ise rotobarlı sistem kullanılması gerektiğini, HVI cihazının kullanıma açılması gerektiğini, nadas uygulamasının yapılmasının gerektiğini ve pamukların kuru toplanması gerektiğini belirtmişlerdir.

\section{Sonuçlar}

İşletmelerin çoğunluğunun rollergin çırçır makinesi kullandıkları ve makine sayılarının 50-70 adet arasında değiştiği tespit edilmiştir. 
İşletmelerde çırçır randıman oranının \%3638 arasında gerçekleştiği ortaya çıkmıştır. İşletmeye getirilen kütlünün kirlilik oranının \%40-50 arasında değiştiği, işletmede hem kütlü temizleyici hem de lif temizleyici kullanıldığı görülmüştür.

İsletmeler temizleme işlem sayısının artmasının elyafın kısalmasına sebep olduğu için olumsuz bir durum olarak görmektedir. Kirlilik sorununa çözüm olarak işletmeler, pamuğun temiz toplanması gerektiğini, yaprak döktürücülerin zamanında ve yeterli miktarda kullanılması gerektiğini ve bunun için de çiftçilerin bilinçlendirilmesi gerektiğini belirtmişlerdir.

İşletmeler makineli hasadı daha temiz ve randımanı yüksek olduğu için tercih etmektedirler. İşletmeler, pamuğun bölge ekonomisine olan katkısının yeterli olmadığını, bunun için fabrikaların da desteklenerek istihdamın arttırılması gerektiğini bildirmişlerdir.

İşletmeler çiftçilerden kaliteli ve temiz pamuğun yanı sıra daha bilinçli olmalarını beklemektedir. İşletmelerin karşılaştıkları sorunlardan en önemlisi kütlü alımında ve lif pamuğun satış ve pazarlamasıdır. Bunu güven, bilinçsizlik ve pahalı girdi izlemektedir. İsletmelerin tek balya kontrol sistemi hakkında yeterli bilgiye sahip oldukları; ancak bu uygulamayı gerçekleştirmedikleri görülmektedir.

Lif kalitesini arttırmak için işletmelerin sundukları önerilerin başında sertifikalı tohum kullanılması gelmektedir. Bunu, çiftçilerin bilinçlendirilmesi ve hasatta pamuğun temiz toplanması izlemektedir. Çırçır fabrikaları ile yapılan çalışmada elde edilen veriler ışığında, aşağıdaki öneriler yapılabilir.

- Çiftçi bilinçlendirilmeli,

- Sertifikalı tohum kullanılmalı,
- Pamuğun tarlada temiz toplanması için sosyolojik, ekonomik ve teknolojik yöntemler belirlenmeli,

- Münavebe yapılmalı,

- Pamuk fiyatları sabitlenmeli,

- Çırçır fabrikalarında modern teknoloji kullanılmalı,

- Tek balya kontrol sistemine geçilmeli,

- Lisanslı depoculuk yapılmalı,

- Denetimler arttırılmalıdır.

\section{Kaynaklar}

Çopur, O., 2014. Lif Bitkileri Ders Notları. Harran Üniversitesi Ziraat Fakültesi Tarla Bitkileri Bölümü. Şanlıurfa, 170s.

Kaya, H., Toklu, P., Dolançay, A., Türkoğlu, Ş.R., Nasırcı, Z., Süllü, S., Özbek, B.S., 2007. Adana, Hatay, Gaziantep ve Kahramanmaraş illerinde Bulunan Çırçır Işletmelerinin Genel Durumu, Kütlü Pamuğa Iliş̧in Kalite Beklentileri, Sorunları ve Çözüm Önerileri. Türkiye VII. Tarla Bitkileri Kongresi, 25-27 Haziran, 548-553s. Erzurum.

Oğlakçı, M., Bölek, Y., Çopur, O., 2007. Pamukta Hasat, Depolama ve Çırçırlama. 2007. Ticaret Borsası Yayınları-3, Şanlıurfa, 98s. ISBN: 978-9944-60-162-7.

Oğlakçı, M., 2012. Pamuk Bitkisel Yapısı, Yetiştirilmesi, Islahı ve Lif Teknolojisi. Akademisyen Kitapevi, Ankara. ISBN: 978605-464-922-8.

Özel, E., 2015. Türkiye'deki Çırçır-Linter-Prese Işletmelerinin Durumlarının İncelenmesi. Yüksek Lisans Tezi, Kahramanmaraş Sütçü İmam Üniversitesi Fen Bilimleri Enstitüsü, Kahramanmaraş, $102 \mathrm{~s}$.

TÜik, 2016. www.tuik.gov.tr (Erişim tarihi: 05.06.2016).

Tümer, H.T., 2010. Çırçırlama Yöntemlerinin Pamuk Kalitesi Üzerine Etkileri. Yüksek Lisans Tezi, Çukurova Üniversitesi Fen Bilimleri Enstitüsü, Adana, 51s. 